\title{
Pramoxine containing topical formulation of eberconazole in the management of dermatophytosis in India: a consensus statement
}

\author{
Uday Khopkar ${ }^{1}$, Shyamanta Barua ${ }^{2}$, Sanjay Kumar Rathi ${ }^{3}$, A. N. Tiwari ${ }^{4}$, Balakrishna Nikam ${ }^{5}$, \\ Chitra Nayek $^{6}$, Hemen Shah ${ }^{7}$, H. M. Srinivas ${ }^{8}$, Praneetha Kest', P. V. S. Prasad ${ }^{10}$, \\ Rajesh Katariya $^{11}$, Rathish Pillai ${ }^{12}$, Satyaprakash Mahajan ${ }^{13}$, Saurabh K. Mishra ${ }^{14}$, \\ Yaseen Umar ${ }^{15}$, Monil Yogesh Neena Gala ${ }^{16 *}$, Snehal Sameer Muchhala ${ }^{16}$
}

\author{
${ }^{1}$ Department of Dermatology and Venereology at KEM Hospital and GS Medical College Mumbai, Maharashtra, India \\ ${ }^{2}$ Department of Dermatology, Assam Medical College and Hospital, Dibrugarh, Assam, India \\ ${ }^{3}$ Dr Sanjay K Rathi Clinic, Siliguri, West Bengal, India \\ ${ }^{4}$ Skin Institute, Lucknow, Uttar Pradesh, India \\ ${ }^{5}$ Krishna Institute of Medical Science, Karad, Maharashtra, India \\ ${ }^{6}$ Department of Dermatology, BYL Nair Charitable Hospital and TN Medical College, Mumbai, India \\ ${ }^{7}$ Healin Touch Clinic, Mumbai, Maharashtra, India \\ ${ }^{8}$ Skin Cosmetic Clinic, Bangalore, Karnataka, India \\ ${ }^{9} \mathrm{R}$ K Medical Centre, Anakapalli, Andhra Pradesh, India \\ ${ }^{10}$ Skin Care Clinic, Chidambaram, Tamil Nadu, India \\ ${ }^{11}$ Well Skin Clinic, Indore, Madhya Pradesh, India \\ ${ }^{12}$ Azeezia Medical College Hospital, Kerala, India \\ ${ }^{13}$ Dr Satyaprakash Mahajan Skin Care Clinic, Nashik, Maharashtra, India \\ ${ }^{14}$ The Leprosy Mission Trust India, Delhi, India \\ ${ }^{15}$ Government Medical College, Anantnag, Jammu and Kashmir, India \\ ${ }^{16}$ Dr Reddy's Laboratories, Hyderabad, Telangana, India
}

Received: 02 August 2021

Revised: 13 October 2021

Accepted: 14 October 2021

\section{*Correspondence:}

Dr. Monil Yogesh Neena Gala,

E-mail: monil.yogesh@drreddys.com

Copyright: () the author(s), publisher and licensee Medip Academy. This is an open-access article distributed under the terms of the Creative Commons Attribution Non-Commercial License, which permits unrestricted non-commercial use, distribution, and reproduction in any medium, provided the original work is properly cited.

\section{ABSTRACT}

Dermatophytosis, a superficial fungal infection has attained significant extents among Indian population. Its clinical presentation is diverse, often in terms of morphology, severity type and involvement of all age groups. Management of dermatophytosis has become an important public health issue in India. Cases of steroid modified dermatophytosis are being encountered frequently, mostly caused due to the inadvertent use of steroid in combination with topical antifungal agents. This combination is available over the counter and is often used for the management of inflammation and pruritis associated with the disease. Current treatment recommendations must be reviewed as per the current clinical scenario of the disease. Thus, a topical formulation of an anti-itch agent like pramoxine and antifungal agent with an anti-inflammatory property like eberconazole holds a promising treatment approach for dermatophytosis. This article focuses on the challenges encountered in the management of dermatophytosis and strategies for optimizing treatment for better patient outcomes. An expert's panel discussion was conducted involving fifteen dermatologists all over India, during which modified Delphi method was executed for a set of nine statements. Agreement of more than $75 \%$ was set to reach the consensus. This consensus document was developed to review the available evidence and make recommendation based on the expert group's opinion for the use of pramoxine containing topical formulation of eberconazole, as it provides the benefit of having an anti-inflammatory and antipruritic activity in a single formulation, where pramoxine can be utilised as an excipient to combat pruritis associated with dermatophytosis.

Keywords: Dermatophytosis, Corticosteroids, Eberconazole, Pramoxine, Tronothane hydrochloride, Azoles 


\section{INTRODUCTION}

Dermatophytosis a superficial fungal infection of skin, hair or nails caused by keratinophilic fungus called 'dermatophytes'. 1 These infections are largely named after the body part they affect like tinea corporis (body), tinea capitis (scalp), tinea cruris (groin), tinea pedis (feet), tinea mannum (hands) and tinea unguium (nails). ${ }^{2-5}$ The warm and humid climate of tropical regions and poor living conditions in crowded areas favour the widespread distribution of dermatophytosis. Local predisposing factors (excessive sweating, friction, walking barefoot), chronic disorders such as diabetes, peripheral vascular disease and more importantly prolonged use of antibiotics or steroids, predisposes an individual to develop dermatophytosis. ${ }^{5-7}$

The worldwide prevalence of superficial fungal infections ranges between $20-25 \% .^{6,8}$ In India, the prevalence of dermatophytosis ranges from $36.6 \%$ to $78.4 \%$ in various hospital-based studies of skin out-patient-department attendees. ${ }^{9}$ Clinical manifestations of dermatophytic infections vary depending upon the causative agent and host immune response. ${ }^{2,9}$ Patient may remain asymptomatic or manifest only as itching or pruritis. Intense pruritis is a common and persistent finding in most cases of dermatophytosis. Though it seems to be a minor symptom, but if present in severe form, it may affect patient's quality of life (QoL). ${ }^{11,12}$ Itch being an unpleasant sensation and having negative influence on QoL, adds to the psychosocial burden of disease. ${ }^{13}$

Topical antifungals mostly imidazole derivatives, fall in the first line of antifungal therapy, and are indicated for dermatophytosis when the lesions are localised. ${ }^{10,14}$ Considering the current scenario in India, use of topical corticosteroids in any type of dermatophytosis is not agreeable as its misuse may result in the persistence of infections leading to chronic and recalcitrant dermatophytosis. ${ }^{14-16}$ Similar recommendation was given in a previously published consensus where the experts, vetoed against the use of topical corticosteroids in any type of dermatophytic infections. Therefore, topical antifungals with anti-inflammatory activity such as eberconazole and steroid sparing antipruritic agent such as pramoxine may form the core of treatment in dermatophytosis. ${ }^{14-16}$

Pramoxine is a local anaesthetic agent which acts by interfering with nerve impulse transmission along the sensory nerve fibres, thereby reducing the sensation of pain and itch. It exerts its anti-pruritic effect by stabilizing the sensory nerve membrane. ${ }^{17,18}$ Thus, it may be used with a potent antifungal agent such as eberconazole, to tackle the problem of itching in the management of dermatophytosis. This consensus document was developed to review the available evidence and make recommendation for the use of pramoxine containing topical formulation of Eberconazole, as it provides the benefit of having an antiinflammatory and anti-pruritic activity in a single formulation, where pramoxine can be utilised as an excipient to combat pruritis associated with dermatophytosis. Further, this document also focuses on the challenges encountered in its management and strategies for optimizing treatment for better patient outcomes.

A panel of 15 expert dermatologists from different regions of India was convened to review the existing literature in the management of dermatophytosis in India. A set of nine statements were specifically prepared on topics pertaining to the prevalence, eberconazole efficacy in dermatophytosis, itch affecting QoL, role of steroids, pramoxine efficacy as an anti-itch and duration of treatment. The potential role of pramoxine containing topical formulation of Eberconazole in the treatment of dermatophytosis was also discussed.

In preparation, an extensive literature search was conducted using the key words "dermatophytosis", "tinea infection", "corticosteroids", "eberconazole", "pramoxine", "tronothane hydrochloride", "itchy tinea", "topical antifungals", "azoles", "anti-histamines", and "recalcitrant", in MEDLINE, Cochrane library, and science direct databases to identify relevant articles. A total of 132 articles were identified out of which 93 were shortlisted. A total of 60 full text articles (review articles, case reports, randomized controlled trials) published in English and in peer-reviewed and indexed journals were selected and the studies with only abstract were excluded.

The panel of fifteen experts (herein after referred to as the expert group) met in a virtual meeting in July 2021, during which the modified Delphi method was used to arrive at a consensus. ${ }^{19}$ After presentation of the existing data, and a thorough discussion amongst the panelists, they were asked to mark their opinion against a set of 9 statements on a modified Delphi scale/method. The expert group provided their vote in an anonymous unbiased manner and added any comments, if found necessary.

The responses provided by the expert group were calculated in terms of percentage of agreement or disagreement. Three-fourths or higher agreement $(\geq 75 \%)$ including agree and neutral response was considered to constitute a consensus. All the items which had failed to reach a consensus were included in the next round of the Delphi technique. Since during our meeting a consensus was formed, third round was not needed. After the consensus meeting, the points of discussion were collated, and the manuscript was circulated among all the experts for review. The percentages of response (agree, neutral, disagree) and the recommendations suggested by the expert group are displayed in Table 1. 
Table 1: Percentage of agreement obtained for statements 1-9 and corresponding expert group recommendations.

\begin{tabular}{|c|c|c|c|}
\hline Point of discussion & $\begin{array}{l}\text { Agreement (\%), } \\
\text { (Agree+neutral) }\end{array}$ & $\begin{array}{l}\text { Disagree } \\
(\%)\end{array}$ & Expert group discussion \\
\hline \multicolumn{4}{|l|}{ Statement 1} \\
\hline $\begin{array}{l}\text { Prevalence of dermatophytosis in India ranges } \\
\text { from } 36.6 \% \text { to } 78.4 \% \text { in hospital outpatient } \\
\text { attendees and itch is commonly found in } \\
\text { dermatophytic infections of glabrous skin }\end{array}$ & 100 & 0 & $\begin{array}{l}\text { Expert group suggested the prevalence } \\
\text { of dermatophytosis range between } 20- \\
60 \%\end{array}$ \\
\hline \multicolumn{4}{|l|}{ Statement 2} \\
\hline $\begin{array}{l}\text { Topical eberconazole is used in dermatophytosis } \\
\text { because of its pharmacological properties }\end{array}$ & 100 & 0 & $\begin{array}{l}\text { Expert group agreed to the use of } \\
\text { topical eberconazole in } \\
\text { dermatophytosis }\end{array}$ \\
\hline \multicolumn{4}{|l|}{ Statement 3} \\
\hline $\begin{array}{l}\text { Eberconazole is as effective as other azoles like } \\
\text { sertaconazole and luliconazole in the treatment } \\
\text { of dermatophytic infections }\end{array}$ & 93.33 & 6.67 & $\begin{array}{l}\text { Expert group agreed to the efficacy of } \\
\text { eberconazole is comparable to other } \\
\text { topical azoles in terms of anti- } \\
\text { inflammatory action of eberconazole }\end{array}$ \\
\hline \multicolumn{4}{|l|}{ Statement 4} \\
\hline $\begin{array}{l}\text { Most of the patient with dermatophytosis } \\
\text { complains of itch. Itch affects QoL due to its } \\
\text { effects on sleep }\end{array}$ & 100 & 0 & $\begin{array}{l}\text { Expert group suggested that itch get } \\
\text { affects QoL as it causes sleep } \\
\text { disturbances }\end{array}$ \\
\hline \multicolumn{4}{|l|}{ Statement 5} \\
\hline $\begin{array}{l}\text { Corticosteroids alone or in combination with } \\
\text { antifungals have undesirable effects in the } \\
\text { management of dermatophytosis. }\end{array}$ & 100 & 0 & $\begin{array}{l}\text { Expert group agrees to the abuse of } \\
\text { corticosteroids in dermatophytosis, and } \\
\text { the undesirable effects caused due to } \\
\text { their use. }\end{array}$ \\
\hline \multicolumn{4}{|l|}{ Statement 6} \\
\hline $\begin{array}{l}\text { Pramoxine, as a topical anti-itch agent, has } \\
\text { shown adequate tolerability and efficacy }\end{array}$ & 93.33 & 6.67 & $\begin{array}{l}\text { Expert group agreed to the tolerability } \\
\text { and efficacy of pramoxine as an anti- } \\
\text { itch agent. }\end{array}$ \\
\hline
\end{tabular}

\section{Statement 7}

The minimum duration of treatment of pramoxine containing eberconazole formulation ranges from 2-4 weeks in naïve cases and longer 8 in recalcitrant cases and after relief of pruritis,

8020
plain eberconazole can be used

\section{Statement 8}

In persistent itchy dermatophytosis, Pramoxine can help in reducing the usage of antihistamines
93.33
Expert group suggested rule of two to be followed in the treatment of dermatophytosis

\section{Statement 9}

Pramoxine containing topical antifungals have the potential to reduce the abuse of topical steroid and antifungal combination in treatment of cutaneous dermatophytosis

\section{Statement 9a.}

Could pramoxine containing antifungal therapy be used as an alternative to antifungal and corticosteroid combination

\section{Statement 9b.}

Pramoxine as an anti-itch for mild, moderate or severe cases

\section{Statement 9c.}

Duration of therapy for pramoxine containing antifungal therapy in different dermatophytosis
Expert group agreed that Pramoxine can help in reducing the usage of oral antihistamines

Expert group agreed that Pramoxine containing topical antifungal provide a safe alternative to use of antifungal steroid combination in treatment of cutaneous dermatophytosis

Pramoxine containing antifungal therapy can be used in treatment of dermatophytosis and use of topical steroid and antifungal combination should be strongly discouraged

Pramoxine as an anti-itch can be used in mild, moderate and severe cases

The minimum duration of treatment of pramoxine containing antifungal therapy ranges from 2-4 weeks in naïve cases and longer in recalcitrant cases 


\section{DISCUSSION}

Statement 1: Prevalence of dermatophytosis in India ranges from $36.6 \%$ to $78.4 \%$ in hospital outpatient attendees and itch is commonly found in dermatophytic infections of glabrous skin.

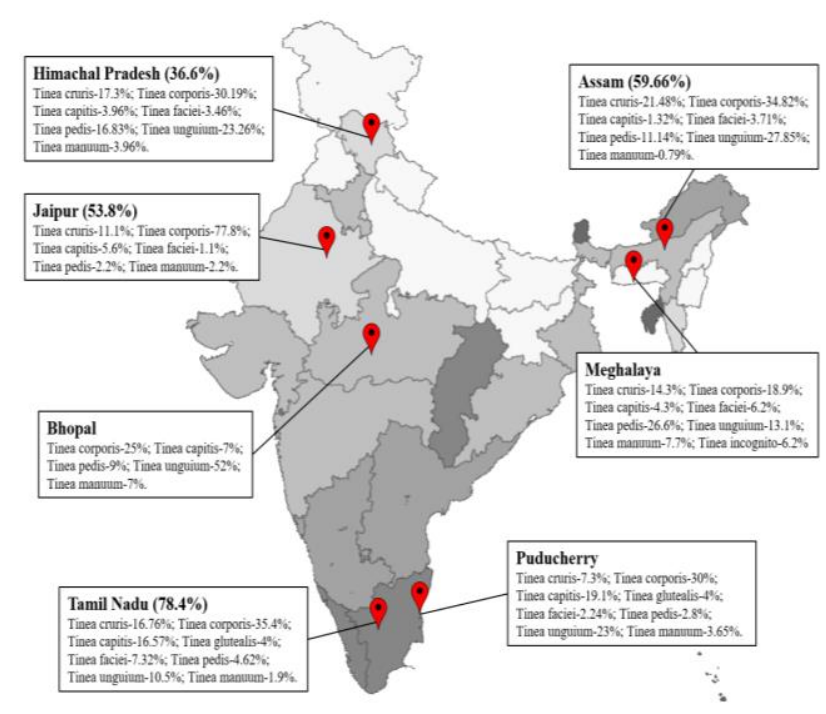

Figure 1: Prevalence of dermatophytosis and its types in India.

India being a tropical region with hot and humid weather conditions, favours the development of dermatophytic infections. Various studies reported a large variation in its prevalence throughout the country ranging from $36.6 \%$ to $78.4 \% .^{9,14}$ However, the expert group opined that these figures were somewhat higher than their practical experience. A range of $15 \%$ to $50 \%$ would be nearer to reality, they expressed. Reported prevalence of dermatophytic infections and its types in India is presented in Figure 1.

Itch is a constant clinical element in dermatophytosis and the literature addressing its prevalence and clinical characteristics is less. Only one study evaluated the prevalence, clinical characteristics and intensity of itch in patients suffering from superficial dermatophytosis with a mean duration assessed from $6.3 \pm 18$ months, and $89.9 \%$ reported itch limited to skin lesions. Moreover, $74.7 \%$ reported itch intensity as "severe" and "very severe". ${ }^{13}$

Statement 2: Topical eberconazole is used in dermatophytosis because of its anti-fungal and antiinflammatory pharmacological properties

Eberconazole, an imidazole derivative, is an effective topical antifungal agent having fungicidal activity at high concentrations. It is known to possess broad spectrum antimicrobial activity and acts by inhibiting ergosterol synthesis leading to functional and structural changes in the cell membrane and also exerts an anti-inflammatory action by inhibiting 5- lipoxygenase (5-LO) and to a lesser extent cyclo-oxygenase-2 (COX-2). This property is useful in reducing the inflammatory component of dermatophytosis and enhancing the treatment compliance. $^{20,21}$ Spectrum of activity of eberconazole is presented in Figure 2. Additionally, it possesses antibacterial property similar to sertaconazole against gram positive bacteria. $^{20}$ Eberconazole $1 \%$ cream formulation consists of lipophilic-hydrophilic molecular structure which helps in better penetration of drug into the cell membrane and prolong its duration of action. ${ }^{21}$ Additionally, Bothiraja et al investigated ethyl cellulose micro sponges as topical carriers of eberconazole nitrate and found four-fold higher retention of eberconazole nitrate in the stratum corneum layer compared to commercial cream, which may lead to increased efficacy of the drug. ${ }^{22}$

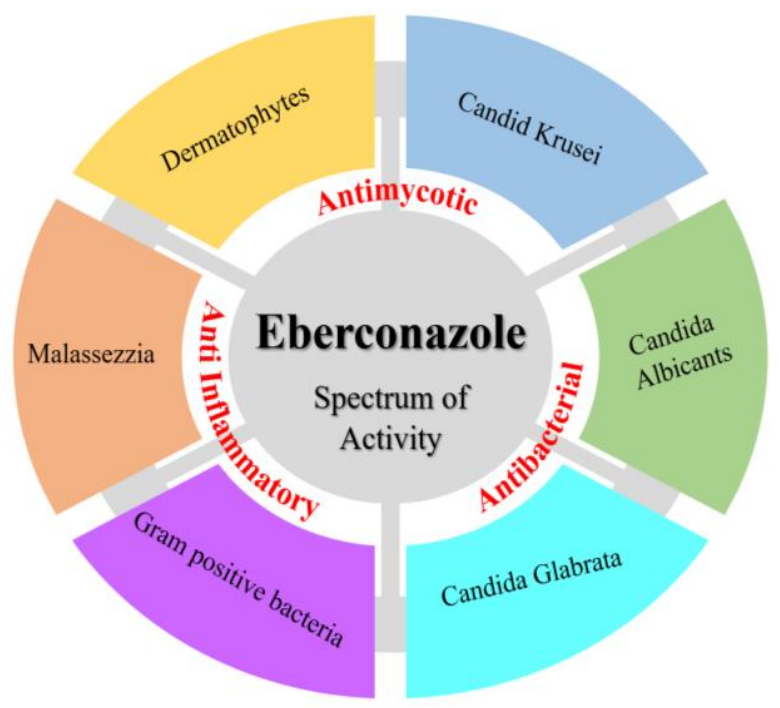

Figure 2: Spectrum of activity of eberconazole.

In a prospective, observational study among Indian patients, $1 \%$ eberconazole cream showed significant improvement in total signs and symptoms score in tinea corporis and tinea cruris patients within the first week of treatment. After 3 weeks of treatment, mean percent reduction score of signs and symptoms was $76.8 \%$ for scaling, $61.2 \%$ for itching and $60.3 \%$ for erythema. Physicians' global assessment of effectiveness, safety and acceptability was reported to be good to excellent at the end of third week. Based on the evidence form real world setting and post-hoc analysis, it was concluded that $1 \%$ eberconazole cream is an effective and safe treatment in the management of tinea corporis and tinea cruris infection. $^{23}$

Statement 3: Eberconazole is as effective as other topical azoles, like sertaconazole and luliconazole in the treatment of dermatophytosis.

Randomised controlled trial (RCT) conducted by Montero et al reported the clinical efficacy of $1 \%$ eberconazole to be $76.1 \%$ among 360 dermatophytosis 
patients along with a good safety and tolerability profile. ${ }^{24}$ Similarly, in another RCT $(n=75)$ conducted by Nakka et al $1 \%$ eberconazole demonstrated better clinical improvement and fungal clearance in comparison to luliconazole and sertaconazole. Moreover, results showed resolution of pruritis in $72.7 \%$ of patients in eberconazole group followed by luliconazole $(50 \%)$ and sertaconazole $(33.3 \%) .{ }^{25}$ Similarly, a study comparing $1 \%$ terbinafine
HCL and $1 \%$ eberconazole found that eberconazole nitrate was as effective as terbinafine HCL. However, complete cure with Eberconazole was $93.3 \%$ at the end of second week whereas it was $80 \%$ for terbinafine. ${ }^{26}$ Comparison of MIC values of various antifungals are shown in Table 2. Efficacy of topical eberconazole in comparison to other antifungals is shown in the below Table 3 .

Table 2: Comparison of minimum inhibitory concentration (MIC) values of various antifungal agents.

\begin{tabular}{|c|c|c|c|c|c|c|c|c|c|c|c|c|}
\hline Variables & EBZ & TRB & ITR & FLU & VRC & KTC & AMB & GRIS & MCZ & CLT & LUZ & SER \\
\hline $\begin{array}{l}\text { T. } \\
\text { mentagrophytes }\end{array}$ & $\begin{array}{l}0.016- \\
1\end{array}$ & $0.015-8$ & $0.015-1$ & $\begin{array}{l}0.12- \\
32\end{array}$ & - & - & - & $\begin{array}{l}0.5- \\
128\end{array}$ & - & - & - & - \\
\hline T. interdigitale & $0.125-1$ & $\begin{array}{l}0.015 \geq 3 \\
2\end{array}$ & $\begin{array}{l}0.015 \geq 1 \\
6\end{array}$ & $0.5 \geq 64$ & $\begin{array}{l}0.031>1 \\
6\end{array}$ & $\begin{array}{l}0.062- \\
64\end{array}$ & $0.25-8$ & $\begin{array}{l}0.5- \\
128\end{array}$ & $\begin{array}{l}0.25 \\
\geq 16\end{array}$ & $0.08-32$ & $\begin{array}{l}0.0035- \\
0.5\end{array}$ & $\begin{array}{l}0.03 \\
\geq 16\end{array}$ \\
\hline $\begin{array}{l}\text { T. } \\
\text { mentagrophytes } \\
\text { interdigitale } \\
\text { complex }\end{array}$ & - & $\begin{array}{l}0.015- \\
32\end{array}$ & $\begin{array}{l}0.0078- \\
1\end{array}$ & $\begin{array}{l}0.0625- \\
64\end{array}$ & $\begin{array}{l}0.0078- \\
4\end{array}$ & $\begin{array}{l}0.0078- \\
2\end{array}$ & - & $\begin{array}{l}0.25- \\
128\end{array}$ & $0.03-4$ & $0.007-2$ & $0.03-1$ & $0.007-2$ \\
\hline T. rubrum & $\begin{array}{l}0.032- \\
0.05\end{array}$ & $\begin{array}{l}0.015-1 \\
6\end{array}$ & $0.015-1$ & $0.03-32$ & $0.031-4$ & $0.062-1$ & - & $\begin{array}{l}0.5- \\
128\end{array}$ & & $0.125-2$ & $\begin{array}{l}<.007- \\
0.25\end{array}$ & $0.03-2$ \\
\hline T. tonsurans & $\begin{array}{l}0.03- \\
0.125\end{array}$ & $0.015-2$ & $\begin{array}{l}0.0625- \\
2\end{array}$ & $2-16$ & $\begin{array}{l}0.0625- \\
2\end{array}$ & $0.125-1$ & 8 & 32 & 8 & $0.25-32$ & $\begin{array}{l}0.062- \\
0.031\end{array}$ & $\begin{array}{l}0.125 \\
>16\end{array}$ \\
\hline T. violaceum & $0.03-0.25$ & 0.06 & 0.25 & 8 & $<0.03$ & 0.25 & 0.25 & 1 & 0.25 & 0.5 & $<.007$ & 1 \\
\hline
\end{tabular}

TRB=Terbinafine; ITR=Itraconazole; FLU=Fluconazole; VRC=Voriconazole; KTC=Ketoconazole; AMB=Amphotericin $\quad$ B; GRIS=Griseofulvin; $\mathrm{MCZ}=$ Miconazole $; \mathrm{CLT}=$ Clotrimazole; $\mathrm{LUZ}=$ Luliconazole; $\mathrm{SER}=$ Sertaconazole, $\mathrm{EBZ}=$ Eberconazole

Table 3: Efficacy of topical eberconazole in comparison to other antifungals.

\begin{tabular}{|c|c|c|c|c|}
\hline $\begin{array}{l}\text { Authors } \\
\text { (Year) }\end{array}$ & Type of study & $\begin{array}{l}\text { Sample } \\
\text { size }\end{array}$ & Methods & Results \\
\hline $\begin{array}{l}\text { Choudhary } \\
\text { et } \mathbf{a l}^{26}(2014)\end{array}$ & RCT & 42 & $\begin{array}{l}1 \% \text { terbinafine vs } 1 \% \\
\text { eberconazole } \\
\text { for } 3 \text { weeks }\end{array}$ & $\begin{array}{l}\text { Complete cure was obtained in both groups } \\
(\mathrm{p}<0.05) . \\
\text { However, complete cure with eberconazole was } \\
93.3 \% \text { at the end of } 2^{\text {nd }} \text { week as compared to } \\
80 \% \text { for terbinafine. } \\
1 \% \text { eberconazole nitrate was as effective as } 1 \% \\
\text { terbinafine HCL }\end{array}$ \\
\hline $\begin{array}{l}\text { Sharma et } \\
\text { al (2018) }\end{array}$ & $\begin{array}{l}\text { Open label, } \\
\text { randomised, } \\
\text { comparative CT }\end{array}$ & 60 & $\begin{array}{l}1 \% \text { terbinafine vs } 1 \% \\
\text { eberconazole } \\
\text { For } 2 \text { weeks }\end{array}$ & $\begin{array}{l}\text { Early response was observed with eberconazole } \\
\text { at the end of } 1^{\text {st }} \text { week }(\mathrm{p}=0.009) \text {. } \\
\text { Complete cure rates were } 80 \% \text { vs } 63.3 \% \text {. } \\
\text { Clinical and mycological cure was better with } \\
\text { eberconazole than terbinafine }(\mathrm{p}>0.05) \text {. }\end{array}$ \\
\hline $\begin{array}{l}\text { Nakka et } \\
\mathrm{al}^{25}(2020)\end{array}$ & $\begin{array}{l}\text { Randomised, } \\
\text { open label, } \\
\text { prospective } \\
\text { study }\end{array}$ & 75 & $\begin{array}{l}1 \% \text { eberconazole vs } \\
2 \% \text { sertaconazole vs } \\
1 \% \text { luliconazole } \\
\text { For } 4 \text { weeks }\end{array}$ & $\begin{array}{l}\text { Pruritis relief achieved by eberconazole } 1 \% \\
\text { cream was more }(72.7 \%) \text { followed by } 1 \% \\
\text { luliconazole }(50 \%) \text { and }(33.3 \%) 2 \% \\
\text { sertaconazole }(33.3 \%) \text { at } 4 \text { weeks. } \\
\text { Reduction in scaling was more with } \\
\text { eberconazole }(90.9 \%) \text { followed by sertaconazole } \\
(87.5 \%) \text { and luliconazole }(83.3 \%) \text {. } \\
\text { Clinical cure at the end of } 4 \text { weeks was better } \\
\text { with eberconazole. }\end{array}$ \\
\hline $\begin{array}{l}\text { Thomas et } \\
\text { al }^{23}(2020)\end{array}$ & $\begin{array}{l}\text { Prospective, } \\
\text { Single arm, } \\
\text { observational } \\
\text { Study }\end{array}$ & 104 & $\begin{array}{l}1 \% \text { eberconazole } \\
\text { cream }\end{array}$ & $\begin{array}{l}\text { After } 2 \text { weeks of treatment, signs and symptom } \\
\text { score }<2 \text { was observed in } 25 \% \text { of patients. } \\
\text { After } 3 \text { weeks of treatment, total sign and } \\
\text { symptom score was } 60.3 \% \text { for erythema, } 61.2 \% \\
\text { for itching, and } 76.8 \% \text { for scaling. } \\
1 \% \text { eberconazole cream was found to be } \\
\text { effective and safe treatment option in the } \\
\text { management of tinea corporis and cruris in } \\
\text { Indian patients. }\end{array}$ \\
\hline
\end{tabular}




\section{Statement 4: Most of the patients with dermatophytosis complain of itch. Itch affects QoL due to its effect on sleep.}

Itching or pruritis is an unpleasant feeling, which causes a negative impact on psychological wellbeing. Though it seems to be a minor symptom, but if present in severe form, it may affect patient's QoL. ${ }^{11,12}$ Verma et al reported the negative impact of itch on sleep pattern and well-being in 99 patients, wherein $34.3 \%$ patients reported difficulties in falling asleep and $54.6 \%$ complained of sleep awakenings. A significant correlation between the intensity of itch and QoL impairment was found $(\mathrm{p}<0.002)$. Itch being an unpleasant sensation and having negative influence on QoL, adds to the psychosocial burden of disease. ${ }^{13}$

Pruritis is a major concern in patients suffering from superficial dermatophytosis. Its occurrence may be associated with the inflammatory response of the host. ${ }^{13}$ It elicits the urge to scratch leading to a vicious itchscratch-itch cycle which results in disruption of skin integrity, compromising the barrier resistance to infections. ${ }^{27}$ Only one study conducted in Vadodara and

Mumbai evaluated the prevalence, clinical characteristics and intensity of itch in patients suffering from dermatophytosis with a mean duration assessed from $6.3 \pm 18.0$ months, and $89.9 \%$ reported itch limited to skin lesions. Moreover, $74.7 \%$ reported itch intensity as "severe" and "very severe"; $34.3 \%$ patients experienced itch as an isolated sensation, whereas others showed associated symptoms such as burning (46.9\%), stinging $(10.1 \%)$ and biting sensation $(7.1 \%){ }^{13}$

\section{Statement 5: Corticosteroids alone or in combination with antifungals have undesirable effects in the management of dermatophytosis.}

Corticosteroids by virtue of their anti-inflammatory action, have been extensively used either alone or in combination with azoles in the treatment of dermatophytosis. ${ }^{28}$ Use of topical corticosteroids in any type of dermatophytosis is not agreeable due to its undesirable effects, most importantly tinea pseudoimbricata and tinea incognito. Verma et al. reported six cases of steroid modified tinea cruris and tinea corporis manifesting as tinea pseudo-imbricata, a specific cutaneous form of fungal infection, caused due to injudicious use of topical preparations containing steroids. $^{29}$ Alston et al. reported persistent/recurrent infection of tinea corporis in children treated with the combination of clotrimazole $1 \%$ with $0.05 \%$ betamethasone dipropionate cream. ${ }^{30}$ Considering the current scenario in India, use of topical corticosteroids in any type of dermatophytosis is not recommended. ${ }^{14}$ Sheth et al reported four cases of tinea incognito caused due to inappropriate use of potent topical corticosteroids. Patients experienced severe itching and aggravation of the existing fungal infection, later recovering with the use of oral and topical antifungals. ${ }^{31}$ Additionally, a retrospective study reported tinea incognito in 54 children, among which topical steroids were used in the treatment either alone $(68.5 \%)$ or in combination with an antifungal or an antibiotic (32\%). ${ }^{32}$ Tinea incognito is an atypical clinical presentation of dermatophytic infection caused due improper use of corticosteroids. ${ }^{33}$ Several studies reported the association between topical corticosteroid use and tinea incognito, in which the dermatophytosis has lost its usual clinical appearance due to misuse of steroid. ${ }^{34-36}$ Topical steroids are widely used due to their immediate symptom relief. Lack of awareness among population and its abuse by local physicians and lack of strict regulations all contribute to the undesirable effects caused by improper steroid use. ${ }^{31}$

\section{Statement 6: Pramoxine, as a topical anti-itch agent, has shown adequate tolerability and efficacy.}

Pramoxine is a morpholine derived surface anaesthetic agent that is well tolerated on the skin and mucous membrane. ${ }^{18,37}$ It reduces the sensation of pain and itch by interfering with nerve impulse transmission along the sensory nerve fibres and exerts its anti-pruritic effect by stabilizing the sensory nerve membrane. ${ }^{17}$ Use of Pramoxine as an anti-pruritic agent date back to 1954. Tronothane hydrochloride (HCL), a brand of pramoxine HCL (cream and gel) was used in the treatment of 200 patients suffering with pruritic dermatoses as a twice daily application for a length of time varying from $24 \mathrm{hrs}$ to 5 months. The efficacy was judged based on the subjective symptoms and tronothane HCL was found to be effective in reducing pruritis in $57 \%$ of cases. No sensitization reaction was reported and tronothane HCL was reported as a moderately satisfactory antipruritic medication. ${ }^{38}$ Zhai et al in his histamine induced itch experiment, reported that $1 \%$ pramoxine formulation has significantly reduced the itch magnitude and itch duration $(\mathrm{p}<0.05)$ in 10 volunteers and also stated that pramoxine cream formulation was more effective in comparison to $1 \%$ hydrocortisone formulation and other vehicle controls. ${ }^{17}$ Young et al reported that $1 \%$ pramoxine HCL used for 4 weeks showed $61 \%$ decrease in average visual analogue score (VAS) in the treatment of uremic pruritis in haemodialysis patients with no adverse effects reported. Pramoxine HCL was suggested as a safe, convenient and effective topical product in treating uremic pruritis. ${ }^{39}$ Rosen et al included pramoxine in the therapeutic ladder of neuropathic pruritis for treating mild itch. ${ }^{40}$ Several studies have reported that pramoxine was well tolerated with no adverse effects and sensitization issues. ${ }^{38,39,41}$ Studies showing the efficacy of pramoxine as an anti-itch agent are mentioned in Table 4. 
Table 4: Efficacy and safety profile of pramoxine as an anti-pruritic agent.

\begin{tabular}{|c|c|c|c|c|c|}
\hline $\begin{array}{l}\text { Authors } \\
\text { (Year) }\end{array}$ & Type of study & $\begin{array}{l}\text { Sample } \\
\text { size }\end{array}$ & Methods & $\begin{array}{l}\text { Clinical } \\
\text { conditions }\end{array}$ & Results \\
\hline $\begin{array}{l}\text { Noojin }^{38} \\
(\mathbf{1 9 5 4 )}\end{array}$ & - & $\begin{array}{l}200 \\
12\end{array}$ & $\begin{array}{l}1 \% \text { tronothane } \\
\text { HCL* cream and } \\
1 \% \text { tronothane } \mathrm{HCL} \\
\text { jelly } \\
1 \% \text { tronothane } \mathrm{HCL} \\
\text { vs } \\
\text { Placebo (Base } \\
\text { without tronothane } \\
\text { HCL) }\end{array}$ & $\begin{array}{l}\text { Pruritic } \\
\text { dermatoses } \\
\text { (Lichen } \\
\text { simplex } \\
\text { chronicus, } \\
\text { infantile } \\
\text { eczema, } \\
\text { psoriasis, } \\
\text { urticaria etc.) }\end{array}$ & $\begin{array}{l}\text { Tronothane HCL effective in } \\
\text { reducing pruritis in } 57 \% \text { of } \\
\text { cases. } \\
\text { No sensitization reaction was } \\
\text { reported. } \\
\text { Jelly was cosmetically less } \\
\text { acceptable by the patients and } \\
\text { less effective in reducing } \\
\text { itching. } \\
\text { Placebo preparation was less } \\
\text { effective in the } 8 \text { of } 12 \\
\text { patients }\end{array}$ \\
\hline $\begin{array}{l}\text { Cream et al } \\
(\mathbf{2 0 0 4 )}\end{array}$ & $\begin{array}{l}\text { Open label, } \\
\text { single centre, } \\
\text { observer blinded, } \\
\text { controlled trial }\end{array}$ & 24 & $\begin{array}{l}\text { Lactic acid with } \\
\text { ammonium } \\
\text { hydroxide }+1 \% \\
\text { pramoxine HCL } \\
\text { vs } \\
\text { control (No } \\
\text { treatment) }\end{array}$ & $\begin{array}{l}\text { Women with a } \\
\text { H/O dry skin }\end{array}$ & $\begin{array}{l}\text { Significant improvement of } \\
\text { dry skin grades and severity } \\
\text { of itch was observed with test } \\
\text { cream by day } 1(\mathrm{p}<0.0001) \\
\text { compared to control. } \\
\text { Dry skin and itch continued } \\
\text { to improve through day } 7 \\
(\mathrm{p}<0.0001) \text {. } \\
\text { No clinically significant } \\
\text { adverse effects were reported } \\
\text { during the study. }\end{array}$ \\
\hline $\begin{array}{l}\text { Zhai et al }{ }^{17} \\
(2002)\end{array}$ & $\begin{array}{l}\text { Experimental } \\
\text { study }\end{array}$ & 10 & $\begin{array}{l}\text { Three }(1 \% \\
\text { hydrocortisone Vs } \\
\text { three } 1 \% \text { pramoxine } \\
\text { formulation }\end{array}$ & $\begin{array}{l}\text { Histamine } \\
\text { induced itch } \\
(100 \mu \mathrm{g} \\
\text { histamine } \\
\text { dihydro } \\
\text { chloride) }\end{array}$ & $\begin{array}{l}1 \% \text { pramoxine formulation } \\
\text { significantly reduced the itch } \\
\text { magnitude and itch duration } \\
(\mathrm{p}<0.05) \text { and was more } \\
\text { effective in comparison to } 1 \% \\
\text { hydrocortisone formulation } \\
\text { and other vehicle controls. }\end{array}$ \\
\hline $\begin{array}{l}\text { Young et } \\
\text { al, (2009) }\end{array}$ & $\begin{array}{l}\text { Randomized, } \\
\text { double blind, } \\
\text { controlled } \\
\text { comparative trial }\end{array}$ & 28 & $\begin{array}{l}\text { Topic } 1 \% \\
\text { Pramoxine twice } \\
\text { daily for } 4 \text { weeks, } \\
(n=14) \text { vs } \\
\text { cetaphil lotion, } \\
(n=14)\end{array}$ & Uremic pruritis & $\begin{array}{l}61 \% \text { decrease in itch intensity } \\
\text { in pramoxine group and } 12 \% \\
\text { in control group and rate of } \\
\text { decline in itching was greater } \\
\text { with pramoxine with no } \\
\text { adverse effects reported. } \\
\text { Pramoxine HCL was } \\
\text { suggested as a safe, } \\
\text { convenient and effective } \\
\text { topical product in treating } \\
\text { uremic pruritis }\end{array}$ \\
\hline
\end{tabular}

HCL=Hydrochloride, Tronothane HCL* $=$ Brand name of pramoxine hydrochloride.

Statement 7: The minimum duration of treatment of pramoxine containing eberconazole formulation ranges from 2-4 weeks in nä̈ve cases and longer in recalcitrant cases and after relief of pruritis, plain eberconazole can be used.

Tinea cruris and tinea corporis are usually treated with systemic antifungals for four to six weeks and sometimes for longer duration, while tinea pedis is treated with an azole for four to eight weeks and sometimes longer. As per 'American academy of family physicians' recommendation, treatment with topical antifungals should be continued one week post clinical resolution. ${ }^{14,42}$
Treatment algorithm of dermatophytosis is presented in Figure 3. According to Kikhani et al almost all types of dermatophytosis infections require 2-4 weeks treatment and may extend up to 6 months in tinea capitis and onychomycosis. ${ }^{5}$

The current expert group felt that the duration of topical therapy should be used for at least two weeks after the stoppage of systemic therapy.

In a multicentric, double blind, randomized trial, $1 \%$ eberconazole nitrate cream applied twice daily for 4 weeks, showed clinical efficacy of $76.1 \%$ vs $75 \%$ in 
miconazole group in the treatment of dermatophytosis with a good safety profile. ${ }^{24}$ Similarly, RCT of 133 patients evaluated efficacy of $1 \%$ eberconazole vs $1 \%$ clotrimazole cream applied twice daily for 4 weeks in dermatophyte infections and found an effective result among $61 \%$ patients of eberconazole group vs $46 \%$ patients of clotrimazole treated group. ${ }^{43}$ In another study, 60 patients with tinea corporis and tinea cruris were treated with $1 \%$ eberconazole cream once daily (group A, 15 patients), $1 \%$ twice daily (group B, 15 patients), $2 \%$ once daily (group C, 15 patients), and $2 \%$ twice daily (group D, 15 patients). Treatment was continued 2 weeks post clinical cure to a maximum duration of 6 weeks. No significant difference was observed between the groups in terms of range and mean duration of treatment. However, assessment at 6 weeks post therapy found eberconazole to be effective in $93 \%$ of patients in group A, $100 \%$ of patients in groups B, and D and $61 \%$ of patients in group C. 44

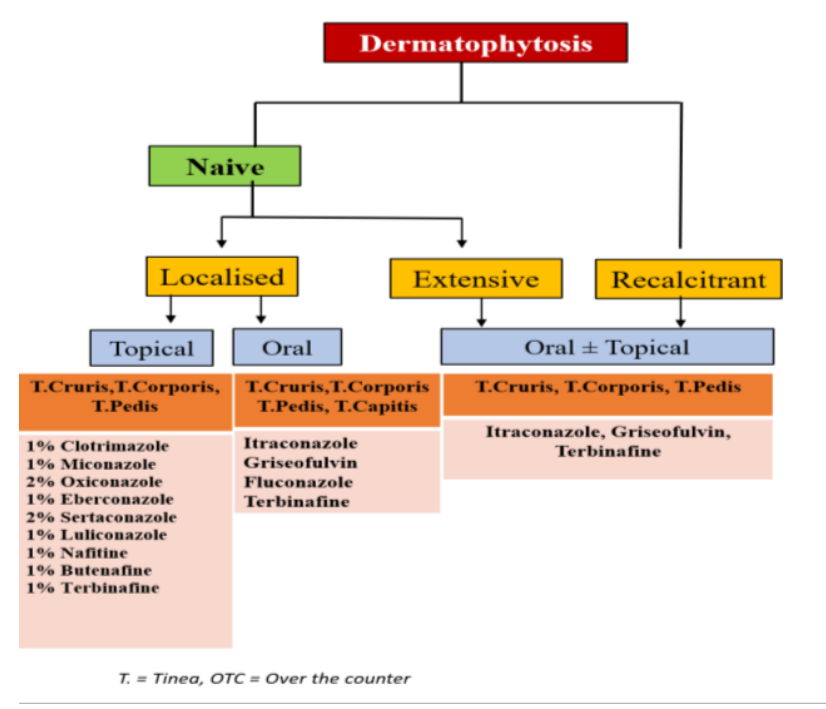

Figure 3: Treatment algorithm of dermatophytosis.

\section{Statement 8: In persistent itchy dermatophytosis, pramoxine can help in reducing the usage of antihistamines.}

Antihistamines, though widely used for pruritis management comes with undesirable side effects such as drowsiness, sedation and anti-cholinergic effects. ${ }^{37,45-47}$ Studies pertaining to efficacy of antihistamines in dermatophytic infections are sparse. Pramoxine has established its role in pruritis management and reported to be well tolerated with low systemic toxicity and sensitization potential. ${ }^{39}$ As mentioned earlier, significant literature is available over the use of pramoxine in dermatologic lesions such as atopic dermatitis, urticaria, uremic pruritis etc but its use as an anti-itch agent in dermatophytosis has not been reported. Therefore, the expert group felt that topical pramoxine when combined with topical antifungals may be helpful in alleviating the itch associated with dermatophytosis and can be used as a substitute to antihistamines.
Statement 9- Pramoxine containing topical antifungals have the potential to reduce the abuse of topical steroid and antifungal combination in treatment of cutaneous dermatophytosis

A strong association is observed between the irrational use of combination creams (antifungal-steroid or antifungal-antibiotic) and recalcitrant cases. Verma et al in literature review including 5 studies, reported frequency of self-administered usage of topical corticosteroid combination cream to be $42 \%-81 \%$ and whereas the frequency of topical antifungal application was $5.7 \%$ to $47 \%$ and stated that topical steroid misuse is an important cause of chronic and recalcitrant dermatophytosis. ${ }^{15}$ Mahajan et al reported that $70.6 \%$ patients applied topical steroids alone or in combination with antifungal or antibacterial agent; and concluded that emergence of resistant strains is probably due to irregular and inadequate use of antifungal drugs. ${ }^{48}$ Therefore, a need arises for an anti-pruritic containing formulation of topical anti-fungal, to reduce the abuse of topical steroid and antifungal combination. And pramoxine due to its low systemic toxicity and sensitization potential can be considered as an anti-pruritic agent in topical antifungal formulation. $^{49}$

\section{CONCLUSION}

Pramoxine has shown its efficacy in managing pruritis associated with dermatologic conditions. While eberconazole by virtue of its anti-inflammatory property can be considered as an ideal antifungal agent; topical application of pramoxine containing formulation of eberconazole could be used as first line of treatment in management of dermatophytosis. The expert group strongly felt that this has potential to emerge as a safe alternative to steroid antifungal combinations that have currently created a man-made epidemic of resistant dermatophytosis.

\section{ACKNOWLEDGEMENTS}

The authors would like to thanks to Isotopes Pvt. Ltd. (www.knowledgeisotopes.com) for the medical writing support provided for the manuscript. We also thank Dr. Rahul Rathod of Dr. Reddy's laboratories for reviewing the manuscript.

Funding: Funding sources from the Dr. Reddy's Laboratories Limited, India, supported the work. Conflict of interest: Dr Snehal and Dr Monil are employees of Dr Reddys Laboratories

Ethical approval: Not required

\section{REFERENCES}

1. Lyngdoh CJ, Lyngdoh WV, Choudhury B, Bora I, Khyriem AB. Clinico-mycological profile of dermatophytosis in Meghalaya. 2013;3(4):2012-4.

2. Ely JW, Rosenfeld S, Stone MS. Diagnosis and 
management of tinea infections. Am Fam Physician. 2014;90(10):702-10.

3. Thai K. Fitzpatrick's dermatology in general medicine. Wiley Online Library. 2008.

4. Shenoy MM, Jayaraman J. Epidemic of difficult-totreat tinea in India: Current scenario, culprits, and curbing strategies. Arch Med Heal Sci. 2019;7(1):112.

5. Al-Khikani F. Dermatophytosis a worldwide contiguous fungal infection: Growing challenge and few solutions. Biomed Biotechnol Res J. 2020;4(2):117-22.

6. Havlickova B, Czaika VA, Friedrich M. Epidemiological trends in skin mycoses worldwide. Mycoses. 2008;52(1):95.

7. Alemayehu A, Minwuyelet G, Andualem G. Prevalence and Etiologic Agents of Dermatophytosis among Primary School Children in Harari Regional State, Ethiopia. J Mycol. 2016;2016:1-5.

8. Heidrich D, Garcia MR, Stopiglia CDO, Magagnin CM, Daboit TC, Vetoratto G et al. Dermatophytosis: A 16-year retrospective study in a metropolitan area in southern Brazil. J Infect Dev Ctries. 2015;9(8):865-71.

9. Naglot A, Shrimali DD, Nath BK, Gogoi HK, Veer V, Chander J et al. Original Research Article Recent Trends of Dermatophytosis in Northeast India (Assam) and Interpretation with Published Studies. Int J Curr Microbiol App Sci. 2015;4(11):111-20.

10. Pires CAA, da Cruz NFS, Lobato AM, de Sousa PO, Carneiro FRO, Mendes AMD. Clinical, epidemiological, and therapeutic profile of dermatophytosis. An Bras Dermatol. 2014;89(2):259-64.

11. Song J, Xian D, Yang L, Xiong X, Lai R, Zhong J. Pruritus: Progress toward Pathogenesis and Treatment. Biomed Res Int. 2018;2018.

12. Patro N, Panda M, Jena AK. The menace of superficial dermatophytosis on the quality of life of patients attending referral hospital in Eastern India: A cross-sectional observational study. Indian Dermatol Online J. 2019;10(3):262.

13. Verma S. Prevalence and clinical characteristics of itch in epidemic- like scenario of dermatophytoses in India : a cross-sectional study. 2019;7-10.

14. Rajagopalan M, Inamadar A, Mittal A, Miskeen AK, Srinivas CR, Sardana K. Expert Consensus on The Management of Dermatophytosis in India (ECTODERM India). 2018;1-11.

15. Verma SB, Panda S, Nenoff $P$, Singal A, Rudramuruthy SM, Uhrlass $S$ et al. The unprecedented epidemic-like scenario of dermatophytosis in India: I. Epidemiology, risk factors and clinical features. Indian $\mathrm{J}$ Dermatol Venereol Leprol. 2021;87(2):154-75.

16. Elmariah SB, Lerner EA. Topical therapies for pruritus. Semin Cutan Med Surg. 2011;30(2):118-26.

17. Zhai H, Simion FA, Abrutyn E, Koehler AM, Maibach HI. Screening topical antipruritics: A histamine-induced itch human model. Skin
Pharmacol Appl Skin Physiol. 2002;15(4):213-7.

18. Pramocaine. Available at: https://pubchem.ncbi. nlm.nih.gov/compound/Pramocaine. Accessed on July 112021 .

19. McMillan SS, King M, Tully MP. How to use the nominal group and Delphi techniques. Int $\mathrm{J}$ Clin Pharm. 2016;38:655-62.

20. Sahni K, Singh S, Dogra S. Newer topical treatments in skin and nail dermatophyte infections. Indian Dermatol Online J. 2018;9(3):149.

21. Moodahadu LS, Patnaik A, Arvind VV, Bhide RM. Preclinical pharmacological profile of Eberconazole : A review and update. 2014;5(2):159-65.

22. Bothiraja C, Gholap AD, Shaikh KS, Pawar AP. Investigation of ethyl cellulose microsponge gel for topical delivery of eberconazole nitrate for fungal therapy. Ther Deliv. 2014;5(7):781-94.

23. Thomas J, Das S, Ghate S, Chatterjee M, Teltumde $\mathrm{S}$, Charugulla SN et al. Effectiveness and safety of eberconazole $1 \%$ cream in Indian patients with Tinea corporis and Tinea cruris: a prospective real-world study. Int J Res Dermatology. 2020;7(1):96.

24. Montero TR, López S, Rodríguez C, del Rio R, Badell A, Gratacós MR. Eberconazole 1\% cream is an effective and safe alternative for dermatophytosis treatment: Multicenter, randomized, double-blind, comparative trial with miconazole $2 \%$ cream. Int $\mathbf{J}$ Dermatol. 2006;45(5):600-4.

25. Nakka AR, Bommakanti J, Karumuri SRR, Thambisetti NB. Evaluation of newer imidazoles in dermatophytosis. 2020;6(1):75-9.

26. Choudhary S, Aghi T, Bisati S. Efficacy and safety of terbinafine hydrochloride $1 \%$ cream vs eberconazole nitrate $1 \%$ cream in localised tinea corporis and tinea cruris. Indian Dermatol Online J. 2014;5(2):128.

27. Liebel F, Lyte P, Garay M, Babad J, Southall MD. Anti-inflammatory and anti-itch activity of sertaconazole nitrate. Arch Dermatol Res. 2006;298(4):191-9.

28. Havlickova B, Friedrich M. The advantages of topical combination therapy in the treatment of inflammatory dermatomycoses. Mycoses. 2008;51(4):16-26.

29. Verma S, Hay RJ. Topical steroid-induced tinea pseudoimbricata: a striking form of tinea incognito. Int J Dermatol. 2015;54(5):e192-3.

30. Alston SJ, Cohen BA, Braun M. Persistent and recurrent tinea corporis in children treated with combination antifungal/corticosteroid agents. Pediatrics. 2003;111(1):201-3.

31. Sheth HJ, Rathod SP, Chaudhary RG, Malhotra SD, Patel PR. Tinea incognito with unjustified use of potent Topical Corticosteroids: a case series. Int $\mathbf{J}$ Basic Clin Pharmacol. 2017;6(8):2087.

32. Del Boz J, Crespo V, Rivas-Ruiz F, de Troya M. Tinea incognito in children: 54 cases. Mycoses. 2011;54(3):254-8.

33. Bornali Dutta ESR, Bobita B. Clinico-epidemiological study of tinea incognito 
with microbiological correlation. Indian $\mathbf{J}$ Dermatology, Venereol Leprol. 2017;83:3.

34. Jacobs JA, Kolbach DN, Vermeulen AH, Smeets MH, Neuman HA. Tinea incognito due to Trichophytom rubrum after local steroid therapy. Clin Infect Dis. 2001;33(12):142-4.

35. Elghblawi E. Extensive 'Tinea Incognito' Due to Topical Steroid: A Case Report. JMED Res. 2013;2013:1-3.

36. Indramaya DM, Karim A, Ahmad Z. A Case of Tinea Incognito: A Misuses of Steroid. Berk Ilmu Kesehat Kulit dan Kelamin. 2019;31(3):242-7.

37. Brunton LL, Hilal-Dandan R, Knollmann BC. Goodman and Gilman's the pharmacological basis of therapeutics. McGraw-Hill Education New York; 2018.

38. NOOJIN RO. Tronothane hydrochloride (pramoxine hydrochloride) in the control of pruritus. Postgrad Med. 1954;16(5):453-5.

39. Young TA, Patel TS, Camacho F, Clark A, Freedman BI, Kaur M et al. A pramoxine-based antiitch lotion is more effective than a control lotion for the treatment of uremic pruritus in adult hemodialysis patients. J Dermatolog Treat. 2009;20(2):76-81.

40. Rosen JD, Fostini AC. Diagnosis and Management of Neuropathic Itch Pruritus Neuropathic Diagnosis Treatment Peripheral nerves. Dermatol Clin. 2018;02:005

41. SCHWARTZ FR. Tronothane in common pruritic syndromes. Postgrad Med. 1954;16(1):19-21.

42. Weinstein A, Berman B. Topical treatment of common superficial tinea infections. Am Fam Physician. 2002;65(10):2095-102.

43. Del PA, Ortiz FJ, Pérez A, Pazos C, Garau M, Font E. A double-blind randomized comparative trial:
Eberconazole $1 \%$ cream versus clotrimazole $1 \%$ cream twice daily in Candida and dermatophyte skin infections. Mycoses. 2001;44(5-6):173-80.

44. Del Palacio A, Cuétara S, Noriega AR. Topical treatment of tinea corporis and tinea cruris with eberconazole (WAS 2160) cream 1\% and 2\%: a phase II dose-finding pilot study: Topische Behandlung der Tinea corporis und Tinea cruris mit Eberconazol-(WAS 2160)-1\% und-2\%-Creme: Eine Phase-II-Dos. Mycoses. 1995;38(7-8):317-24.

45. Harrison IP, Spada F. Breaking the Itch-Scratch Cycle: Topical Options for the Management of Chronic Cutaneous Itch in Atopic Dermatitis. Medicines. 2019;6(3):76.

46. Fallon JD, Sober A. Relief of pruritus in patients with atopic dermatitis after treatment with topical doxepin cream. J Am Acad Dermatol. 1994;31(4):613-6.

47. Lynn A. Drake, MD; Larry E. Millikan M. The Antipruritic Effect of 5\% Doxepin Cream. Arch Dermatol. 1995;(131):1403-8.

48. Mahajan S, Tilak R, Kaushal SK, Mishra RN, Pandey SS. Clinico-mycological study of dermatophytic infections and their sensitivity to antifungal drugs in a tertiary care center. Indian $\mathbf{J}$ Dermatology, Venereol Leprol. 2017;83(4):436.

49. Noble SL, Forbes RC, Stamm PL. Diagnosis and management of common tinea infections. Am Fam Physician. 1998;58(1):163.

Cite this article as: Khopkar U, Barua S, Rathi SK, Tiwari AN, Nikam B, Nayek C et al. Pramoxine containing topical formulation of eberconazole in the management of dermatophytosis in India: a consensus statement. Int J Res Dermatol 2022;8:175-84. 